\title{
New Avian Breeding Records for Iqaluit, Nunavut
}

\section{David J. T. Hussell ${ }^{1,2}$, Jeremy A. T. Hussell ${ }^{2}$, and ERicA H. DunN ${ }^{2,3,4}$}

${ }^{1}$ Ontario Ministry of Natural Resources, Wildlife Research and Development Section, 2140 East Bank Drive, Peterborough, Ontario K9J 7B8 Canada

2111 Decou Road, Simcoe, Ontario N3Y 4K2 Canada

${ }^{3}$ Environment Canada, National Wildlife Research Centre, Carleton University, 1125 Colonel By Drive, Ottawa, Ontario K1A 0H3 Canada

${ }^{4}$ Corresponding author

Hussell, David J. T., Jeremy A. T. Hussell, and Erica H. Dunn. 2012. New avian breeding records for Iqaluit, Nunavut. Canadian Field-Naturalist 126(1): 59-60.

Breeding was documented for the first time in Iqaluit, Nunavut, for Savannah Sparrow (Passerculus sandwichensis), Whitecrowned Sparrow (Zonotrichia leucophrys), and Dark-eyed Junco (Junco hyemalis), extending the known breeding ranges in the eastern Arctic for all three species.

Key Words: Savannah Sparrow, Passerculus sandwichensis, White-crowned Sparrow, Zonotrichia leucophrys, Dark-eyed Junco, Junco hyemalis, breeding, Iqaluit.

We conducted field work in and around Iqaluit, Nunavut, on various dates between 16 June and 5 September in 2007, 2008, 2009, 2010, and 2011. Our main objective was to study the the Northern Wheatear (Oenanthe oenanthe) (Bairlein et al. 2012), but we also documented new breeding records for the following three species.

Passerculus sandwichensis (Savannah Sparrow)

This species was recorded only in 2011. An adult was seen and photographed by R. Nagel on 3 July; and on 21 July, JATH saw an adult feeding the fledgling in Figure $1 \mathrm{~A}\left(63^{\circ} 45.3^{\prime} \mathrm{N}, 68^{\circ} 27.8^{\prime} \mathrm{W}\right)$. A bird seen in flight on 10 August may have been a juvenile.
Zonotrichia leucophrys (White-crowned Sparrow)

Single young birds in first basic plumage were seen on 1 September 2007 and on 2 and 3 September 2008. Adults were seen along the shore path between Iqaluit and Apex village on eight days between 30 June and 28 July 2010. One of these White-crowned Sparrows was singing (14 July). JATH saw an adult feeding fledglings on 8 July $\left(63^{\circ} 44.0^{\prime} \mathrm{N}, 68^{\circ} 28.7^{\prime} \mathrm{W}\right)$ and photographed one of them. On 28 July, DJTH saw and photographed another adult that was feeding fledglings

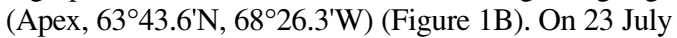
2011, JATH and DJTH found a pair feeding recently fledged young and photographed one of the adults (Tarr

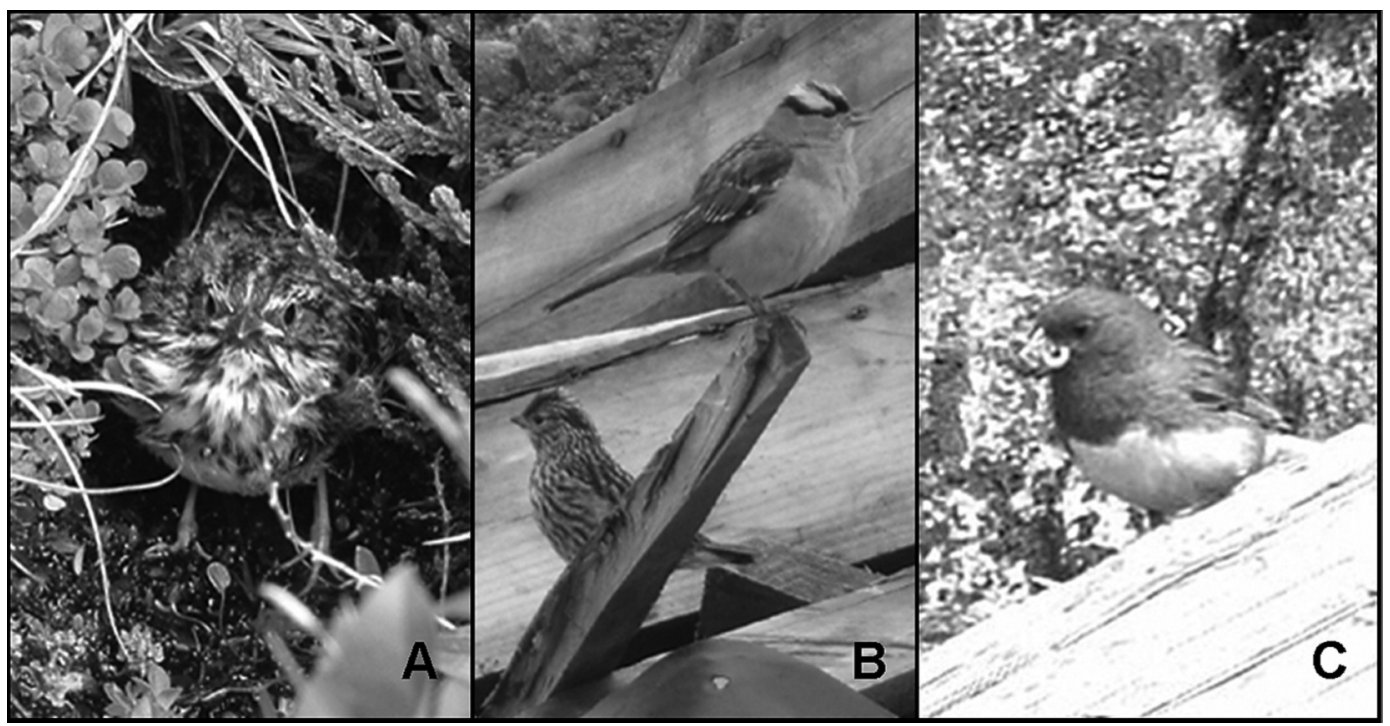

FIGURE 1. Evidence of breeding from Iqaluit, Nunavut. A. Fledgling Savannah Sparrow that was being fed by an adult, 21 July 2011. Photo: J. A. T. Hussell. B. Adult White-crowned Sparrow (upper right) with fledgling it was feeding, 28 July 2010. Photo: D. J. T. Hussell. C. Dark-eyed Junco carrying food for nearby young, 22 July 2011 Photo: J. A. T. Hussell. 
Inlet, $63^{\circ} 43.7^{\prime} \mathrm{N}, 68^{\circ} 23.8^{\prime} \mathrm{W}$ ). All adults that were closely observed, including all of those attending fledglings, were of the eastern subspecies, Z. l. leucophrys.

\section{Junco hyemalis (Dark-eyed Junco)}

Dark-eyed Juncos were reported to us in 2007 (with a photograph), and we saw them repeatedly between 1 July and 25 July 2010 (five dates) and 25 June and 22 July 2011 (at least nine dates). Many of the latter birds were singing. We estimated that at least five adults were present in late June and early July of 2011. On 22 July, JATH found a pair gathering food and feeding at least two fledglings near Apex $\left(63^{\circ} 43.4^{\prime} \mathrm{N}, 68^{\circ} 26.9^{\prime} \mathrm{W}\right)$. He photographed one of the adults carrying food (Figure 1C).

\section{Discussion}

Vagrants of these three species have been reported at scattered locations in the Canadian Arctic Archipelago (Godfrey 1986; Gaston and Ouellet 1997; Northwest Territories/Nunavut Bird Checklist Program*; eBird*). In 1957, a White-crowned Sparrow was found on Fletcher's Ice Island (a tabular iceberg used as a research station) $\left(82^{\circ} 37^{\prime} \mathrm{N}, 99^{\circ} 50^{\prime} \mathrm{W}\right)$, only $240 \mathrm{~km}$ from the North Pole (Godfrey 1986); and a juvenile Dark-eyed Junco was present on Tern Island $\left(75^{\circ} 48^{\prime} \mathrm{N}\right.$, $96^{\circ} 18^{\prime} \mathrm{W}$ ) from 4 to 30 August 2011 (Mark Mallory, personal communication).

According to Richards and White $\left(2008^{*}\right)$, all three species have also bred in the arctic islands, but we were able to obtain details for only the Dark-eyed Junco (J. Richards, personal communication). That species has been found tending fledglings on both Coats and East Digges islands, in northeastern Hudson Bay. The White-crowned Sparrow has recently been documented breeding in the western Arctic at Cambridge Bay, Victoria Island (J. Richards, personal communication), a site farther north than Iqaluit.

Although the records from Iqaluit extend known breeding ranges in the eastern Arctic to north of the Hudson Strait, they may not represent recent expansion, and are not necessarily evidence of response to climate change. Our parties of up to six people spent 4-10 hours daily for 2-6 weeks annually searching for nests and broods of Northern Wheatear. The sparse records we have for sparrows and Dark-eyed Junco indicate that evidence of breeding could easily have been overlooked previously. Moreover, the periphery of the northern range may be occupied only sporadically. Illustrating this is the fact that we saw and suspected breeding of American Robins (Turdus migratorius) in Iqaluit each year from 2007 to 2010, but saw no robins at all in 2011.

\section{Acknowledgements}

Some of the observations reported here in 20092011 were made by our colleagues F. Bairlein, M. Bulte, R. Nagel, D. R. Norris, and D. Strickland. For help and advice in Iqaluit, we thank M. Mallory (Canadian Wildlife Service, Environment Canada) and M. E. Thomas and R. Armstrong (both with the Nunavut Research Institute). Our research was supported by Bird Studies Canada. Author sequence was determined by drawing lots.

\section{Documents Cited (marked * in text)}

eBird. National Audubon Society and Cornell Lab of Ornithology, Ithaca, New York. http://ebird.org/ebird/eBirdReports ?cmd=Start. Accessed August 2012.

Northwest Territories/Nunavut Bird Checklist Survey. Canadian Wildlife Service, Environment Canada, Yellowknife, Northwest Territories. http://www.ec.gc.ca/reom-mbs /default.asp?lang=En\&n=60E48D07-1. Accessed August 2012.

Richards, J., and T. White. 2008. Birds of Nunavut: a checklist. Revised edition. Published by the authors. http://avi base.bsc-eoc.org/links/reports/Nunavut_Bird_Checklist.pdf. Accessed August 2012.

\section{Literature Cited}

Bairlein, F., D. R. Norris, R. Nagel, M. Bulte, C. C. Voigt, J. W. Fox, D. J. T. Hussell, and H. Schmaljohann. 2012. Cross-hemisphere migration of a $25 \mathrm{~g}$ songbird. Biology Letters 8: 505-507; published ahead of print February 15, 2012, doi:10.1098/rsbl.2011.1223.

Gaston, A. J., and H. Ouellet. 1997. Birds and mammals of Coats Island, Northwest Territories. Arctic 50: 101-118.

Godfrey, W. E. 1986. The Birds of Canada. Revised edition. National Museum of Natural Sciences, National Museums of Canada, Ottawa.

Received 29 December 2011

Accepted 29 February 2012

ADDENDUM: On 29 June 2012, DJTH found a pair of eastern White-crowned Sparrows feeding 5 young, about 6-7 days old, in a ground nest under a patch of willows (Salix sp.) at Apex $\left(63^{\circ} 43.8^{\prime} \mathrm{N}, 68^{\circ} 27.1^{\prime} \mathrm{W}\right)$. 